\title{
FROM RUNES TO THE NEW MEDIA AND DIGITAL BOOKS
}

\section{FOREWORD}

This issue brings together contributions from several fields and their intersections with a variety of approaches: linguistics, cultural studies, film studies and literature. It would also be accurate to say that all the papers the editors have gathered here have a poignant anthropological dimension through an interest which goes beyond their object, further into the larger context of human culture shaped by English, in different ages. We consider the ways in which writing in English shaped a language which has become the world's most used, the lingua franca of our contemporary world. Whether we look at its linguistic development of alphabetic writing from the Germanic runes, with their pre-alphabetic origins, or at the "newspaperized world" (p.39) of Punch, which marked the beginning of an era dominated by the media in the English-speaking world, or at the "deeply intercultural and intermedial" (p.17) ways in which a late Victorian writer like William Morris combined the art of calligraphy and textile, wall-paper, carpet, etc. crafts with his passion for letters (in their many senses) and foreign literatures, or at "the communal efforts of (re-)shaping and (re-) defining what it meant to be a Jew and what it meant to be a JewishAmerican" by translating "personal written histories, submitted in different languages" (p.47) into English, or at "the Blitz Gothic" style developed by Elizabeth Bowen in the line of an Irish tradition rooted in Bram Stoker's and John Banville's writing, or at the Australian Aboriginal literature in English, or at the films directed by John Ford, which are iconic for the "foundation of a romantic, heroic America and the forging of American national character" (p.69) or at "the cultural impact and oral tradition of the music, songs and books of Pete Seeger" (p.75) the "legendary folk musician's career [which] spanned eight decades and touched on many of the key historical developments of the day" (p.75) and beyond, or at the Texas/Mexico border culture issues in Gloria Anzaldua's Borderlands/La Frontera, or at how books, through their material and spititual nature, and reading them impact us, we reach the same conclusion: the culture written in or translated into English is not only a phenomenon but a 
complex process, where a variety of languages, cultures and media crosspollinate and cross-fertilize.

In the paper which opens this issue, Adrian Poruciuc tackles the history of script, which belongs in the field of "visual communication" (p.8). His argument, which draws on the most recent findings in the field, is that neither Egyptian hieroglyphs, nor Mesopotamian cuneiforms represent alphabetic systems. In addition to this approach, which throws our deep-seated notions of the very origins of script into serious question, Poruciuc sheds new light on the long debate whether, at its origins, the earliest forms of script served "practical uses", or, as the most recent scholarly studies, including those undertaken by Gimbutas, Haarmann, Merlini, Lazarovici, Mair and Winn suggest, "divination and magic" (p.8). Starting from these premises, the author's incursion into the enthralling history of script demonstrates that "the rather peculiar features of the Germanic runes," which appeared late in this timeline, "reflect, practically, all the stages of the history of writing: from pictograms to abstract-looking logograms, and finally to phonograms, that is, to alphabetic signs” (p.8). Relying on illustrative examples of Elder Fupark (EF) inscriptions, which is the earliest version of the runic script, Poruciuc's position in the scientific quarrel between the supporters of the "practical use" hypothesis versus those of the "divination and magic" one is to side with those "who consider that most of the Germanic runes, by their shapes and/or names, show roots in ancient magic and in divinatory practices" (p.14).

The legacy of an intermedial and intercultural designer and man of letters such as William Morris is yet another epitome of the complexity of visual communication. Focusing her paper on Morris's so far rather neglected love of letters both as script and as graphic design, Isabelle Gadoin unravels the "crosscultural and trans-disciplinary sources” (p.17) of the Victorian scholar's version of Omar Khayyam's Rubbayiat. Describing and illustrating Morris's laborious and stylish design of the book, in which both letters and exquisite decorations convey the subtlety of meaning, Gadoin argues that the writer believed in "the intimate relationship between text and textile" (p.25). The result of Morris's dedication to the aesthetic principle and method of making the design both as a whole and in its minutest detail endorse and highlight the meaning of the script was the development of "a unified visual idiom, running through his fabrics, wallpapers, books and novels” (p.26). Morris's version of the Rubbayiat was a work of adaptation from several points of view. Gadoin shows that, collaborating with Edward FitzGerald who translated the text, Morris fraught it with the marks of his own style and also with those of Christian concepts, biblical metaphors and paraphrases. Thus, Morris's work of adaptation typifies an essential method of cultural appropriation developed by the artists of the late $19^{\text {th }}$ century: the creation of an aestheticized space where languages, media and cultures fuse and harmonize. 
Making the case for a comparative study of the first two important grammars in the English and Romanian language respectively, Dana Dobos bridges cultural and linguistic distances and reveals the hidden modernity of $18^{\text {th }}$ century descriptive grammars, giving us insight into the fascinating and erudite men behind them. Roberth Lowth's A Short Introduction to English Grammar (1762) and Samuil Micu and Gheorghe Şincai's Elementa linguae dacoromanae sive valachicae (1780) both attempt to educate, inform, and set linguistic and cultural standards, though in different ways and with different goals in mind. The breadth of knowledge and attention to detail in both grammars is not only the mark of great scholarship, but also the mark of great spirits who wanted to elevate and celebrate their respective mother tongues.

Tracing the story of Punch, Simona Avarvarei shows that a magazine does more than just mirror its times: with its combination of text and satirical drawings, Punch honed in on the tastes of the Victorian middle classes, and at the same time shaped those tastes. Quoting David Lodge's account of the impact Punch had on Henry James, Avarvarei argues that the magazine was so much of its times that it provided the American-born writer with the rough sketches of his English characters, their gestures, their attire and their social life. Thus, by reflecting the Victorian Zeitgeist, which was giddy with the excitement of modernity, Punch remolded the world it reflected, giving it its own image: audacious, witty, ironical, blatantly visual - a "newspaperized world" (p.39).

Ştefana Iosif's paper transports us across the Atlantic. Looking into the ways in which the Jewish diaspora managed to preserve their traditions and at the same time adapt to the new cultural environment in America, Iosif contends that autobiographical writing, submitted in different languages and translated into English, gave the Jewish-American community the much needed "venue of expression" in order for them to (re-)define and (re-)shape their new identity.

With Elizabeth Bowen's wartime short story "The Demon Lover" we are on the other side of the Atlantic again. A close reading of Bowen's text gives Florina Năstase a foothold upon which to construct her argument of a genre which she aptly calls "Blitz Gothic." In Năstase's account, this ingenious Gothic, as used by Bowen in her text, suggests that the war itself, which came in two waves and plagued the first half of the $20^{\text {th }}$ century, was "a supernatural occurrence" (p.53). Thus, the literary genre of the Blitz Gothic translates the unnamable monsters beneath the veneer of human civilization and renders them in the form of blood curdling images and tropes, where every word is a hint of inner terror and outer calamity.

Liana Fitzgerald's paper takes us "down under," where we find a literature which was, until relatively recently, oral, and which "still keeps meaning covert to Western readers" (p.58). Fitzgerald shows how Australian Aboriginal literature has been faring to reach us from orality through performance, "to oral translation into English, with its later written form, to 
ultimately broken-down fragments covert within poems or novels” (p.58). We are warned that the Western readers' concepts of time and space, and their ideas and notion of spirituality are a far cry from those of the Australian Aboriginals. However, in the name of what is universal in human understanding that should not deter them from opening themselves up to less familiar cultural and literary experiences.

Irina Chirica broadens the canvas with her focus on the language of the cinema. Her paper looks into the cultural iconicity of John Ford's filmography, arguing that the movies directed by Ford are redolent of a symbolic imagery and cultural significance which typify the culture of the West and American culture at large. Ford's Western movies are so emblematic by virtue of the director's sensibility, which, as Chirica contends, "had one foot in 19th century American thought and feeling, and the other in the $20^{\text {th }}$ century" (p.68). Arguably, it was this kind of sensibility which allowed the American film director to create iconic images of a mythology of the West and to forge the American national character.

The mosaic of the issue gains a new tile with David Livingstone's focus on a legend of American culture, Pete Seeger. Livingstone's is an approach to the oral tradition which nurtures Seeger's work and to the cultural impact and legacy of his music, songs and books. As Livingstone argues, the American artist is the author of "iconic songs which have not only helped define American culture, but even beyond" (p.75). The "beyond" Livingstone means is the plethora of issues in a variety of fields which are still with us today, and which Seeger expressed in his performative art, shared with colleagues and friends, and left as a legacy for the generations to come.

Offering a lyrical and politically-charged reading of Hart Crane's Bridge, Marcela Sulak underlines the inescapable metonymies and nationalistic symbols included in the famous poem dedicated to the Brooklyn Bridge. Sulak makes the case that Crane operates much like the original architects, reenvisioning New York "by recycling elements of the past and recombining them" (p.85) while also revealing the structural limitations of the myth of America. Thus, Sulak argues, the poem is an "open-ended dialogue" (p.84) that does not seek to resolve, but rather to enhance its contradictions.

Gabriela Glăvan focuses on the motif of youth in several of Philip Roth's novels, arguing that youth plays both a constructive and deconstructive part in the fantasies of many of the novel's male protagonists. Youth signals vitality, yet it also acts as a screen for decay and weakness, as the protagonists find out in their relationships with younger women. In their yearning for youth, many of these male heroes "instrumentalized a relationship intended to defy any form of instrumentalization" (p.90), as youth is shown to be an "ironical" and "nostalgic" fantasy (p.90), without possibility of fulfillment for the heroes in question or even the author himself. 
Cătălin Nicolau's paper focuses on Chicana culture and identity expression of the New Mestiza in Gloria Anzaldúa's Borderlands/La Frontera, a hybrid of genres and languages, a book which suffuses prose with poetry, communal history with personal story, written in a language where English and Spanish run into each other, about a space which is neither Texas nor Mexico but the dangerous border between them.

The notes on the materiality and spirituality of books and their being in the world were written in collaboration by a sociologist and a philologist, and they bring the issue to a conclusion. The authors, Dana Bădulescu and Cristina Gavriluţă, who come from two fields, i. e. philology and sociology, argue that beyond their graphics, colours and design, which also give them aesthetic value, books have a spiritual dimension, which is activated by the act of reading. The paper looks both into the scenario of books whose spiritual latency is unfulfilled and into the optimistic scenario when they "become a spiritual and cultural presence in the mind and soul of the Reader" (p.98).

Edited during the coronavirus pandemic, when even those who might have otherwise had face-to-face contact had to keep social distance, this issue is a very timely reminder of the invaluable importance of writing, reading, books, and the many ways in which they intersect with the media, both for the community and for the individual. We hope that this collection of papers will entertain your minds and feed them to new ideas.

September 2020

Dana Janeta BĂDULESCU Florina NĂSTASE 
